\title{
ELEPHANT GRASS SILAGE WITH ADDING OF SOYBEAN HULLS
}

\author{
LIMA,P.G.C. ${ }^{1}$; SOUZA, G. A. ${ }^{2}$; FRANÇA, M. I. ${ }^{1}$; FERRARINI, A. ${ }^{3}$; BRITO, C. M. $^{3}$ \\ ${ }^{1}$ Mestrando do Curso de Pós Graduação em Ciências Veterinárias - UFPR; \\ ${ }^{2}$ Departamento de Zootecnia, UFPR; \\ ${ }^{3}$ Laboratório de Nutrição Animal - UFPR.
}

The objective of the present research is to study a modification on the process of preparation of elephant grass silage (Pennisetum purpureum Schumach), without prewilting, when the plant possesses a large amount of water. The low content of dry matter at the vegetative stage of this forage is the major problem for the fermentative process. The increase of dry matter by the addition of soybean hulls, a residue of low price with a low content of water, has the objective to control the undesirable fermentation through osmotic pressure, by inhibiting the Clostridium bacteria avoiding, this way, the increase of butyric acid production, which promotes the spoiling process on the high humidity silage. For this experiment it has been used napier grass with 56 days of sprout, from a farm from Garuva, at Santa Catarina sea coastal region. As experimental silos PVC $(100 \mathrm{~mm})$ tubs adapted with Brunsen type valves were used. The experimental design used was a randomised complete block with 4 replications evaluating the amount of elephant grass silage and adding different levels of soybean hulls in 5 different treatments: (T1 - 10\%, T2 - 15\%, T3 $20 \%$, T $4-25 \%$ AND T5 $-30 \%$ ), compared with the pre-wilting silage at the sun by 6 hours, (T6). The following parameters were evaluated: Dry Matter (DM), Crude Protein (CP), Total Digestive Nutrients (TDN), Neutral Detergent Fiber (NDF), Acid Detergent Fiber (AFD), and $\mathrm{pH}$. The DM and CP were assayed as described in AOAC (1970). The TDN was calculated according the formula mentioned by KEARL (1982). For the NDF and ADF it was followed the method described by VAN SOEST et al. (1971). The $\mathrm{pH}$ was assayed by means of direct reading on a digital $\mathrm{pH}$-meter. The results showed significant differences $(p<0.05)$ on most of the evaluated parameters. The silages that received addition of soybean hulls were superior in quality than the pre-wilting silage.

Key Words: Elephant Grass, Silage, Dry Matter, Additive, Soybean Hulls. 